\title{
Nitrous oxide, methane emissions and grain yield in rainfed wheat grown under nitrogen enriched biochar and straw in a semiarid environment
}

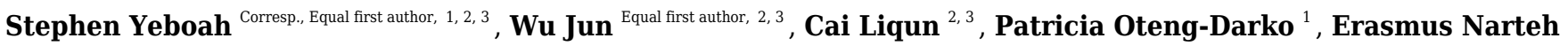
Tetteh $^{4}$, Zhang Renzhi ${ }^{\text {Corresp. 2,3 }}$

${ }^{1}$ CSIR-Crops Research Institute, Kumasi, Ashanti, Ghana

2 College of Resources and Environmental Sciences, Gansu Agricultural University, Gansu, China

3 Gansu Provincial Key Lab of Arid Land Crop Science, Gansu Agricultural University, Gansu, China

${ }^{4}$ Kwame Nkrumah University of Science and Technology (KNUST), Kumasi, Ghana

Corresponding Authors: Stephen Yeboah, Zhang Renzhi

Email address: proyeboah@yahoo.co.uk, zhanrenzi@gmail.com

Background. Soil application of biochar and straw alone or their combinations with nitrogen (N) fertilizer are becoming increasingly common, but little is known about their agronomic and environmental performance in semiarid environments. This study was conducted to investigate the effect(s) of these amendments on soil properties, nitrous oxide $\left(\mathrm{N}_{2} \mathrm{O}\right)$ and methane $\left(\mathrm{CH}_{4}\right)$ emissions and grain and biomass yield of spring wheat (Triticum aestivum L.), and to produce background dataset that may be used to inform nutrient management guidelines for semiarid environments. Methods. The experiment involved the application of biochar straw or urea ( $46 \%$ nitrogen [N]) alone or their

combinations . The treatments were: $\mathrm{CN}_{0}$ - control (zero-amendment), $\mathrm{CN}_{50}-50 \mathrm{~kg} \mathrm{ha}^{-1} \mathrm{~N}$, $\mathrm{CN}_{100}-100 \mathrm{~kg} \mathrm{ha}^{-1} \mathrm{~N}, \mathrm{BN} 0-15 \mathrm{t} \mathrm{ha}^{-1}$ biochar, $\mathrm{BN}_{50}-15 \mathrm{t} \mathrm{ha}^{-1}$ biochar $+50 \mathrm{~kg} \mathrm{ha}^{-1} \mathrm{~N}, \mathrm{BN}_{100^{-}}$ $15 \mathrm{t} \mathrm{ha}^{-1}$ biochar $+100 \mathrm{~kg} \mathrm{ha}^{-1} \mathrm{~N}, \mathrm{SN} 0-4.5 \mathrm{t} \mathrm{ha}^{-1}$ straw, $\mathrm{SN}_{50}-4.5 \mathrm{t} \mathrm{ha}^{-1}$ straw $+50 \mathrm{~kg} \mathrm{ha}{ }^{-1}$ $\mathrm{N}$ and $\mathrm{SN}_{100}-4.5 \mathrm{t} \mathrm{ha}^{-1}+100 \mathrm{~kg} \mathrm{ha}{ }^{-1} \mathrm{~N}$. Fluxes of $\mathrm{N}_{2} \mathrm{O}, \mathrm{CH}_{4}$ and grain yield were monitored over three consecutive cropping seasons between 2014 and 2016 using the static chamber-gas chromatography method. Results. On average, $\mathrm{BN}_{100}$ reported the highest grain yield (2054 $\left.\mathrm{kg} \mathrm{ha}^{-1}\right)$, which was between $25.04 \%$ and $38.34 \%$ higher than all other treatments. In addition, biomass yield was much higher under biochar treated plots relative to the other treatments. These findings are supported by the increased in soil organic $C$ by $17.14 \%$ and $21.65 \%$ in biochar amended soils (at $0-10 \mathrm{~cm}$ ) compared to straw treated soils and soils without carbon respectively. The $\mathrm{BN}_{100}$ treatment also improved bulk density and hydraulic properties $(\mathrm{P}<0.05)$, which supported the above 
results. The greatest $\mathrm{N}_{2} \mathrm{O}$ emissions and $\mathrm{CH}_{4}$ sink were recorded under the highest rate of $\mathrm{N}$ fertilization (100 $\mathrm{kg} \mathrm{N} \mathrm{ha}^{-1}$ ). Cumulative $\mathrm{N}_{2} \mathrm{O}$ emissions were $39.02 \%$ and $48.23 \%$ lower in $\mathrm{BN}_{100}$ compared with $\mathrm{CN}_{0}$ and $\mathrm{CN}_{100}$, respectively. There was also a $\approx 37.53 \%$ reduction in $\mathrm{CH}_{4}$ uptake under $\mathrm{BN}_{100}$ compared with $\mathrm{CN}_{0}$-control and $\mathrm{CN}_{50}$. The mean cumulative $\mathrm{N}_{2} \mathrm{O}$ emission from biochar treated soils had a significant decrease of $10.93 \%$ and $38.61 \%$ compared to straw treated soils and soils without carbon treatment, respectively. However, differences between mean cumulative $\mathrm{N}_{2} \mathrm{O}$ emission between straw treated soils and soils without carbon were not significant. These results indicate the dependency of crop yield, $\mathrm{N}_{2} \mathrm{O}$ and $\mathrm{CH}_{4}$ on soil quality and imply that crop productivity could be increased without compromising on environmental quality when biochar is applied in combination with $\mathrm{N}$-fertilizer. The practice of applying biochar with $\mathrm{N}$ fertilizer at $100 \mathrm{~kg} \mathrm{ha}^{-1} \mathrm{~N}$ resulted in increases in crop productivity and reduced $\mathrm{N}_{2} \mathrm{O}$ and $\mathrm{CH}_{4}$ soil emissions under dryland cropping systems. 


\section{Nitrous oxide, Methane emissions and grain yield in}

2 rainfed wheat grown under nitrogen enriched biochar

3 and straw in a semiarid environment

4

5

6

7

8

9

10

11

12

13

14

15

16

17

18

19

20

21

22

23

24

25

26

27

28

29

30

31

32

33

34

35

36

37

38

39

\section{Stephen Yeboah ${ }^{1,2,3^{*}}$, Wu Jun ${ }^{1,2^{*}}$, Cai Liqun ${ }^{1,2}$, Patricia Oteng-Darko ${ }^{3}$, Erasmus Narteh Tetteh $^{4}$ and Zhang Renzhi ${ }^{1,2}$ \\ ${ }^{1}$ College of Resources and Environmental Sciences, Gansu Agricultural University, Lanzhou, P.R. China}

${ }^{2}$ Gansu Provincial Key Lab of Arid land Crop Science, Gansu Agricultural University, Lanzhou, P.R. China

${ }^{3}$ CSIR-Crops Research Institute, Kumasi, Ghana

${ }^{4}$ Kwame Nkrumah University of Science and Technology (KNUST)

\section{Corresponding Authors:}

Zhang Renzhi; Stephen Yeboah

College of Resources and Environmental Sciences, Gansu Agricultural University, Lanzhou, P.R. China.

Email address: zhangrz@gsau.edu.cn; zhanrenzi@gmail.com; proyeboah@yahoo.co.uk

\section{Abstract}

Background. Soil application of biochar and straw alone or their combinations with nitrogen (N) fertilizer are becoming increasingly common, but little is known about their agronomic and environmental performance in semiarid environments. This study was conducted to investigate the effect(s) of these amendments on soil properties, nitrous oxide $\left(\mathrm{N}_{2} \mathrm{O}\right)$ and methane $\left(\mathrm{CH}_{4}\right)$ emissions and grain and biomass yield of spring wheat (Triticum aestivum L.), and to produce background dataset that may be used to inform nutrient management guidelines for semiarid environments.

Methods. The experiment involved the application of biochar straw or urea ( $46 \%$ nitrogen $[\mathrm{N}])$ alone or their combinations. The treatments were: $\mathrm{CN}_{0}-$ control (zero-amendment), $\mathrm{CN}_{50}-50$ $\mathrm{kg} \mathrm{ha}^{-1} \mathrm{~N}, \mathrm{CN}_{100}-100 \mathrm{~kg} \mathrm{ha}^{-1} \mathrm{~N}, \mathrm{BN}_{0}-15 \mathrm{tha}^{-1}$ biochar, $\mathrm{BN}_{50}-15 \mathrm{tha}^{-1}$ biochar $+50 \mathrm{~kg} \mathrm{ha}^{-}$ ${ }^{1} \mathrm{~N}, \mathrm{BN}_{100}-15 \mathrm{t} \mathrm{ha}^{-1}$ biochar $+100 \mathrm{~kg} \mathrm{ha}^{-1} \mathrm{~N}, \mathrm{SN}_{0}-4.5 \mathrm{tha}^{-1}$ straw, $\mathrm{SN}_{50}-4.5 \mathrm{t} \mathrm{ha}^{-1}$ straw $+50 \mathrm{~kg} \mathrm{ha}^{-1} \mathrm{~N}$ and $\mathrm{SN}_{100}-4.5 \mathrm{tha}^{-1}+100 \mathrm{~kg} \mathrm{ha}^{-1} \mathrm{~N}$. Fluxes of $\mathrm{N}_{2} \mathrm{O}, \mathrm{CH}_{4}$ and grain yield were monitored over three consecutive cropping seasons between 2014 and 2016 using the static chamber-gas chromatography method.

Results. On average, $\mathrm{BN}_{100}$ reported the highest grain yield ( $\left.2054 \mathrm{~kg} \mathrm{ha}^{-1}\right)$, which was between $25.04 \%$ and $38.34 \%$ higher than all other treatments. In addition, biomass yield was much higher 
40 under biochar treated plots relative to the other treatments. These findings are supported by the

41 increased in soil organic $\mathrm{C}$ by $17.14 \%$ and $21.65 \%$ in biochar amended soils (at $0-10 \mathrm{~cm}$ )

42 compared to straw treated soils and soils without carbon respectively. The $\mathrm{BN}_{100}$ treatment also

43 improved bulk density and hydraulic properties $(\mathrm{P}<0.05)$, which supported the above results. The

44 greatest $\mathrm{N}_{2} \mathrm{O}$ emissions and $\mathrm{CH}_{4}$ sink were recorded under the highest rate of $\mathrm{N}$ fertilization (100

$45 \mathrm{~kg} \mathrm{~N} \mathrm{ha}^{-1}$ ). Cumulative $\mathrm{N}_{2} \mathrm{O}$ emissions were $39.02 \%$ and $48.23 \%$ lower in $\mathrm{BN}_{100}$ compared with

$46 \mathrm{CN}_{0}$ and $\mathrm{CN}_{100}$, respectively. There was also a $\approx 37.53 \%$ reduction in $\mathrm{CH}_{4}$ uptake under $\mathrm{BN}_{100}$

47 compared with $\mathrm{CN}_{0}$-control and $\mathrm{CN}_{50}$. The mean cumulative $\mathrm{N}_{2} \mathrm{O}$ emission from biochar

48 treated soils had a significant decrease of $10.93 \%$ and $38.61 \%$ compared to straw treated soils

49 and soils without carbon treatment, respectively. However, differences between mean cumulative

$50 \quad \mathrm{~N}_{2} \mathrm{O}$ emission between straw treated soils and soils without carbon were not significant. These

51 results indicate the dependency of crop yield, $\mathrm{N}_{2} \mathrm{O}$ and $\mathrm{CH}_{4}$ on soil quality and imply that crop

52 productivity could be increased without compromising on environmental quality when biochar is

53 applied in combination with $\mathrm{N}$-fertilizer. The practice of applying biochar with $\mathrm{N}$ fertilizer at

$54100 \mathrm{~kg} \mathrm{ha}^{-1} \mathrm{~N}$ resulted in increases in crop productivity and reduced $\mathrm{N}_{2} \mathrm{O}$ and $\mathrm{CH}_{4}$ soil

55 emissions under dryland cropping systems.

56

\section{Introduction}

58 Atmospheric methane $\left(\mathrm{CH}_{4}\right)$ and nitrous oxide $\left(\mathrm{N}_{2} \mathrm{O}\right)$ are persistent greenhouse gases $(\mathrm{GHG})$

59 influencing global warming (IPCC, 2014). Agriculture contributes significant amounts of $\mathrm{N}_{2} \mathrm{O}$

60 and $\mathrm{CH}_{4}$ to the atmosphere, however net $\mathrm{GHG}$ emissions as $\mathrm{CO}_{2}$ from farming-related activities

61 can be potentially reduced by increasing carbon (C) sequestration in soil and crop biomass

62 (Wang et al., 2021). This may be achieved by implementing improved crop and fertilizer management practices that maximize biomass production and $\mathrm{C}$ returned to soil (Norton, 2014). There are no significant terrestrial sinks of $\mathrm{N}_{2} \mathrm{O}$ hence reduction in its emission may only be achieved by managing nitrogen $(\mathrm{N})$ inputs, and improving soil conditions and efficiency of applied fertilizer-N (Grace, 2016). However, in semi-arid regions of China, in an attempt to increase yields, farmers are compelled to apply more fertilizer, leading to an over-application [Xu and Yang, 2017). There is heavy dependence on mineral fertilizers to ensure adequate $\mathrm{N}$ supply for crops, and in most cases more fertilizer is applied than needed by the plant (Liu et al., 2016).This is a common practice in most farming communities in semi-arid regions of China (Wang et al., 2021). The situation has led to negative impact on the environment, and threatens the long-term sustainability of Chinese agriculture (Liu et al., 2016; Wang et al., 2021). production without compromising on environmental quality.

Current increases in atmospheric GHG levels require that novel approaches are undertaken to mitigate impacts of climate change, such as management practices capable of improving soil C sequestration (Woolf et al., 2010). Soil carbon sequestration through application of recalcitrant $\mathrm{C}$-rich biochar is mentioned as a suitable means to mitigate climate change, and improve soil fertility (Laird et al., 2010) and crop productivity (Steiner et al., 2007). 
80 According to Saggar (2010) $\mathrm{N}_{2} \mathrm{O}$ emissions are driven by the applications of fertilizer nitrogen

81 (N), soil tillage and crop type, with their effects dependent on soil and weather conditions.

82 Biochar application as a soil amendment, could therefore be an effective strategy for mitigating

83 emissions and increasing crop yield. However, the effect of biochar on soil properties, GHG

84 emissions and crop yield have been diverse. Several mechanisms have also been proposed in

85 literature to explain the diverse effects, with limited amounts of evidence to support them. Yanai

86 et al. (2007) reported decreased $\mathrm{N}_{2} \mathrm{O}$ and $\mathrm{CH}_{4}$ soil emissions in response to biochar application.

87 In contrast, Clough et al. (2013) observed no suppression of $\mathrm{N}_{2} \mathrm{O}$ and $\mathrm{CH}_{4}$ soil emissions, whilst

88 similar effect was observed by Zhang et al. (2010). Zhang et al. (2011) also reported that biochar

89 application in dryland significantly reduces soil $\mathrm{CH}_{4}$ emission by $33 \%$ compared to soil without

90 biochar. Zimmerman et al. (2011) attributed the positive effect of biochar application on soil $\mathrm{CH}_{4}$

91 emissions to the inhibition of soil methanotrophs while Zhu et al. (2018) associated reduced soil

$92 \mathrm{CH}_{4}$ emissions to the change in the ratio of methanogenic to methanotrophic archaea. In general,

93 most studies have found biochar amendments to either decrease or not significantly affect soil

$94 \quad \mathrm{~N}_{2} \mathrm{O}$ emissions; however, some few reports have found increased $\mathrm{N}_{2} \mathrm{O}$ emissions following

95 biochar amendments (Yeboah et al., 2018). Explanations for continued long-term suppression of

$96 \mathrm{~N}_{2} \mathrm{O}$ emissions in biochar-amended soils include alterations in microbial communities due to

97 physical habitat changes, physical and/or chemical protection of organic $\mathrm{C}$ and/or $\mathrm{N}$ by biochar

98 and alteration of micro-scale soil redox status due to electrochemical properties of biochars

99 (Rivka et al., 2019). It is thus clear that, these effects have been shown to vary significantly

100 depending upon the type of biochar used and the environmental and soil conditions under which

101 the material is applied.

102

103

The Loess Plateau is an important agricultural area in China and is widely used for grain

104

production (He et al., 2014). The area is one of the most severely eroded regions in China, which coupled with limited precipitation and high evaporation rates, often results in poor crop

105 productivity (He et al., 2014). Many studies have indicated that human activities, such as land use is responsible for the degradation and loss of soil fertility in semi-arid regions of China $(X u$ and Yang, 2017; Zhang et al., 2017; Huang et al., 2019). Traditional methods of soil cultivation often accelerates the decline of soil fertility, and loss of soil organic C (Shirley et al., 2018). Given the fact that the population of semi-arid regions in China mainly relies on rainfed agriculture for their livelihood; developing environmentally friendly and sustainable nutrient management strategies is crucial. There is limited information on the specific impact of widelyused agronomic practices involving biochar, straw and nitrogen fertilizer used alone or combined on greenhouse gas emission and crop yield in drier lossiah soils (Solomon et al., 2007).Moreover, little is known about the effect of biochar application to soil under arid conditions (Arfaoui et al., 2019). This study hypothesized that increased C inputs would raise the soils potential to reduce $\mathrm{N}_{2} \mathrm{O}$ and $\mathrm{CH}_{4}$ soil emissions whilst increasing grain yield. Therefore, the objectives of this study were to: 1) determine the effect of biochar, straw and nitrogen fertilizer applied alone or combined with fertilizer- $\mathrm{N}$ on soil properties, (2) assess the effect of biochar, straw and nitrogen fertilizer applied alone or combined with fertilizer-N on biomass and grain 
120 yield of spring wheat, and (3) determine the effects of biochar, straw and nitrogen fertilizer used

121

122

123

124

125

126

127

128

129

130

131

132

133

134

135

136

137

138

139

140

141

142

143

144

145

146

147

148

149

150

151

152

153

154

155

156

157

158

159

alone or combined with fertilizer- $\mathrm{N}$ on $\mathrm{N}_{2} \mathrm{O}$ and $\mathrm{CH}_{4}$ emissions.

\section{Materials \& Methods}

\section{Study site}

The study was conducted during the 2014, 2015 and 2016 growing seasons at the Dingxi Experimental Station $\left(35^{\circ} 28^{\prime} \mathrm{N}, 104^{\circ} 44^{\prime} \mathrm{E}\right.$, elevation 1971-m above-sea-level) of the Gansu Agricultural University in Northwestern China. The research station is located in the semiarid Western Loess Plateau, which is characterized by step hills and deeply eroded gullies (Feng et al. 2010). This area has Aeolian soils, locally known as Huangmian (Chinese Soil Taxonomy Cooperative Research Group, 1995), which equate to Calcaric Cambisols based on the FAO (1990) description. The soil type in the study area is sandy-loam with low fertility. The soil has a $\mathrm{pH}$ of $\approx 8.3$, soil organic carbon (SOC) $\leq 8.13 \mathrm{~g} \mathrm{~kg}^{-1}$, and Olsen-P $\leq 13 \mathrm{mg} \mathrm{kg}^{-1}$ as described in Yeboah et al. (2018). The type of soil in the study area is the principal soil for cultivation of crops in the agro-ecological zone. Long term average rainfall, evaporation and aridity in the study area is $391.9 \mathrm{~mm}$ per annum; $1531 \mathrm{~mm}$ per annum and 2.53 respectively. The aridity index (AI) is the degree of dryness of the climate at the study area. In July, the daily maximum temperature can increase to $38^{\circ} \mathrm{C}$. Similarly, in January daily minimum temperature can drop to , $-22^{\circ} \mathrm{C}$. Annual cumulative temperatures $>10^{\circ} \mathrm{C}$ are $2240^{\circ} \mathrm{C}$ and annual radiation is $5930 \mathrm{MJ} \mathrm{m}^{-2}$, with $2477 \mathrm{~h}$ of sunshine as described in Yeboah et al. (2018). The agro-climatic conditions are similar to semiarid environments. The research site is characterized by continuous cultivation of the same field using conventional tillage practices. The preceding crop cultivated at the research site was potatoes (Solanum tuberosum L.). Seasonal rainfall recorded in 2014, 2015 and 2016 during the research was 174.6, 252.5 and $239.4 \mathrm{~mm}$ respectively (Fig. 1).

\section{Experimental design and description of treatment}

The experiment involved addition of different carbon (C) sources; namely: biochar and straw, and $\mathrm{N}$ fertilizer in the form of urea $(46 \% \mathrm{~N})$ arranged in a randomized block design with 9 treatments and 3 replications (Yeboah et al., 2018). The treatments were: $\mathrm{CN}_{0}-$ control (zeroamendment), $\mathrm{CN}_{50}-50 \mathrm{~kg} \mathrm{ha}^{-1} \mathrm{~N}$ applied each year, $\mathrm{CN}_{100}-100 \mathrm{~kg} \mathrm{ha}^{-1} \mathrm{~N}$ applied each year, $\mathrm{BN}_{0}-15 \mathrm{tha}^{-1}$ biochar applied in a single dressing in $2014, \mathrm{BN}_{50}-15 \mathrm{tha}^{-1}$ biochar applied in a single dressing in $2014+50 \mathrm{~kg} \mathrm{ha}^{-1} \mathrm{~N}$ applied each year, $\mathrm{BN}_{100}-15 \mathrm{t} \mathrm{ha}^{-1}$ biochar applied in single dressing in $2014+100 \mathrm{~kg} \mathrm{ha}^{-1} \mathrm{~N}$ applied each year, $\mathrm{SN}_{0}-4.5 \mathrm{tha}^{-1}$ straw applied each year, $\mathrm{SN}_{50}-4.5 \mathrm{tha}^{-1}$ straw applied each year $+50 \mathrm{~kg} \mathrm{ha}^{-1} \mathrm{~N}$ applied each year and $\mathrm{SN}_{100}-4.5$ $\mathrm{t} \mathrm{ha}^{-1}$ straw applied each year $+100 \mathrm{~kg} \mathrm{ha}^{-1} \mathrm{~N}$ applied each year as described in Yeboah et al. (2018). The two $\mathrm{C}$ sources (biochar and straw) were applied at the same quantity based on the straw returned to the soil every year and straw $\mathrm{C}$ mineralization. Biochar was spread evenly on the soil surface in March 2014 and incorporated into the soil using a rotary tillage implement to a depth of $\approx 10 \mathrm{~cm}$. The biochar was obtained from Golden Future Agriculture Technology Company Limited, Liaoning in China. Biochar was produced from maize straw using pyrolysis

Peer] reviewing PDF | (2021:01:57597:2:0:NEW 3 Jul 2021) 
160

161

162

163

164

165

166

167

168

169

170

171

172

173

174

175

176

177

178

179

180

181

182

183

184

185

186

187

188

189

190

191

192

193

194

195

196

197

198

199

process at a temperature of $350-550^{\circ} \mathrm{C}$. This process converted about $35 \%$ of the maize straw to biochar. The biochar in the form of granules was milled to a size of $<5 \mathrm{~mm}$ to allow for even mixing with the soil. The wheat crop of the previous season from the research station was used as a source of straw for the study. In the plots that received straw treatment, the straw from the previous wheat crop was weighed and returned to the original plots. This was done after threshing. Biochar analysis was conducted using the procedure as describe in $L u$ (2000). Total $\mathrm{C}$ and $\mathrm{N}$ and soil $\mathrm{pH}$ were determined using a $\mathrm{CN}$ Analyzer (analytikjena; multi N/C, 2100S, Germany) and Kjeldahl digestion and distillation (Bremner and Mulvaney 1982) and $\mathrm{pH}$ meter (model: Sartorius PB-10, Germany). The soil $\mathrm{pH}$ was determined using soil to water ratio of 1 : 2.5. Similar protocol was used to determined total $\mathrm{C}$ and $\mathrm{N}$, ash content and $\mathrm{pH}$ of the straw. Table 1 shows the chemical characterization of biochar and straw used in the experiment. All the treatments received a blanket application of Phosphorus (P) fertilizer which was applied equally at a rate of $46 \mathrm{~kg} \mathrm{ha}^{-1} \mathrm{P}$ in the form of ammonium dihydrogen phosphate $\left(12 \% \mathrm{~N}, 52 \% \mathrm{P}_{2} \mathrm{O}_{5}\right)$. No-tillage seeder was used to incorporate the fertilizer to about $20 \mathrm{~cm}$ soil depth at planting. Based on the protocol described in Yeboah et al. (2016) Spring wheat (Triticum aestivum L. cv. Dingxi 35) was sown in Mid-March at a rate of $188 \mathrm{~kg} \mathrm{ha}^{-1}$ seeds at 20-cm row spacing. The crop was harvested either at the end of July or early August. The individual plot's measured $3 \mathrm{~m}$ by $6 \mathrm{~m}$ and the plots were separated by $0.5 \mathrm{~m}$ width protection rows.

\section{Soil sampling, measurements and analyses}

Based on the protocol described in Yeboah et al. (2016), soil bulk density (BD) was determined by taking small cores and relating the oven-dried mass of soil to the volume of the core. Soil saturated hydraulic conductivity (Ksat) was determined at two points per plot using the disc permeameter method according to Carter (1993). Soil samples were collected from 0-10 and $10-30 \mathrm{~cm}$ depth and bulked for analysis. The samples were processed for analysis using the protocol described in Yeboah et al. (2018). Soil organic carbon (SOC) in the fine ground samples was determined by the modified Walkley and Black (1934) wet oxidation method (Nelson and Sommers, 1982).

\section{Gas sampling and analysis}

Collection of $\mathrm{N}_{2} \mathrm{O}$ and $\mathrm{CH}_{4}$ gases were performed using the static chamber technique based on the procedure described by Zou et al. (2005). For each sampling event, gas collection was consistently performed between 08:00-12:00 h, based on the guidelines of Yeboah et al. (2016). Collection of samples for $\mathrm{N}_{2} \mathrm{O}$ and $\mathrm{CH}_{4}$ analyses was conducted at 0,10 , and 20 minutes after chamber closure. Samples were collected between March and September and detailed sampling procedure could be found in Yeboah et al. (2016; 2018). Based on earlier studies conducted in low rainfall areas (e.g., Wang et al., 2010) emissions occurring during the dry season were expected to be low and therefore did not justify measurements over that period. Gas fluxes were measured over 14 sampling events per year. Whilst acknowledging that accurate estimates of 
200

201

202

203

204

205

206

207

208

209

210

211

212

213

214

215

216

217

220

221

222

223

224

225

226

227

228

229

230

231

232

233

234

235

236

total emissions cannot be determined from relatively few sampling events, the main purpose of this work was to quantify relative differences between-treatments, which therefore justifies the approach used in this study. A similar approach was also employed by Tullberg et al. (2018) to quantify soil emissions of GHG from tillage and traffic treatments in conservation agriculture areas with seasonal rainfall. The $\mathrm{N}_{2} \mathrm{O}$ and $\mathrm{CH}_{4}$ concentration in samples were analyzed within 2 to 3 days after collection using gas chromatograph (GC). The GC system (Agilent 7890A, USA) equipped with flame ionization detector (FID) for $\mathrm{CH}_{4}$ analysis and an electron capture detector (ECD) for $\mathrm{N}_{2} \mathrm{O}$ analysis. Rates of $\mathrm{CH}_{4}$ and $\mathrm{N}_{2} \mathrm{O}$ fluxes were calculated by linear incrementof the gas concentration at 0,10 and $20 \mathrm{~min}$. The calculation was only accepted when the $\mathrm{R}^{2}$ of the linear correlation was higher than $0.90(\mathrm{p}<0.05)$. The average GHG fluxes were a mean of three replicates of each treatment over the sampling dates. Further procedure for the analysis and conditions of the column could be found in Yeboah et al. (2018) and Zou et al. (2005).

\section{Estimations of nitrous oxide and methane emissions}

The $\mathrm{N}_{2} \mathrm{O}\left(\mathrm{mg} \mathrm{m}^{-2} \mathrm{~h}^{-1}\right)$ and $\mathrm{CH}_{4}\left(\mathrm{mg} \mathrm{m}^{-2} \mathrm{~h}^{-1}\right)$ emissions were calculated using Equation (1) based on the protocol described in Yeboah et al. (2016):

$F=\frac{C_{2} \times V \times M_{0} \times 273 / T_{2}-C_{1} \times V \times M_{0} \times 273 / T_{1}}{A \times\left(t_{2}-t_{1}\right) \times 22.4}$

where: $\mathrm{F}$ are fluxes of $\mathrm{N}_{2} \mathrm{O}$ or $\mathrm{CH}_{4}\left(\mathrm{mg} \mathrm{m}^{-2} \mathrm{~h}^{-1}\right), \mathrm{V}$ is volume $\left(\mathrm{m}^{3}\right), \mathrm{M}_{0}$ is the molecular weight of the gas, $\mathrm{C}_{1}$ and $\mathrm{C}_{2}$ are the concentration of previous ( 0 mins) and current ( $\left.20 \mathrm{mins}\right)$ gas concentrations inside the chamber $\left(\mathrm{mol} \mathrm{mol}^{-1}\right), \mathrm{T}_{1}$ and $\mathrm{T}_{2}$ are temperature (Kelvin) recorded inside the chamber during current and previous samplings, and $t_{1}$ and $t_{2}$ are previous and current sampling times $(\mathrm{h})$.

The cumulative emission of $\mathrm{N}_{2} \mathrm{O}$ and $\mathrm{CH}_{4}$ in $\mathrm{kg} \mathrm{ha}^{-1}$ was estimated using the equation as follows (Yeboah et al. 2016):

$$
M=\sum\left(F_{N+1}+F_{N}\right) \times 0.5 \times\left(t_{N+1}-t_{N}\right) \times 24 \times 10^{-2}
$$

where $\mathrm{M}$ is the $\mathrm{N}_{2} \mathrm{O}$ and $\mathrm{CH}_{4}$ cumulative emissions during the period of measurement $(\mathrm{kg}$ $\mathrm{ha}^{-1}$ ), $\mathrm{F}$ is $\mathrm{N}_{2} \mathrm{O}$ and $\mathrm{CH}_{4}$ emission (in $\mathrm{mg} \mathrm{m}^{-2} \mathrm{~h}^{-1}$ ); and previous and current sampling emissions were $\mathrm{N}+1$ and $\mathrm{N}$ respectively. The number of days from first sampling is represented by $\mathrm{t}$.

\section{Biomass and grain yield}

Biomass and grain yield was determined by cutting the plants using hand sickles to $5 \mathrm{~cm}$ height aboveground. The outer edges of about $0.5 \mathrm{~m}$ was discarded from each plot. Both yields were determined on a dry-weight basis by oven-drying the plant material at $105^{\circ} \mathrm{C}$ for 45 min and then to constant weight at $85^{\circ} \mathrm{C}$ (Yeboah et al., 2016). 
238

239

240

241

242

243

244

245

246

247

248

249

250

251

252

253

254

255

256

257

258

259

260

261

262

263

264

265

266

267

268

269

270

271

272

273

274

275

\section{Statistical analyses}

Statistical analyses were undertaken with the SPSS 22 (IBM Corporation, Chicago, IL, USA) with the treatment as the fixed effect and year as random effect. Tukey's honestly significant was used to determine the differences between-treatments means. Significance differences were declared at probability level of $5 \%$.

\section{Results}

\section{Soil bulk density, saturated hydraulic conductivity and soil organic carbon}

Soil samples taken during the study period showed significant differences in the bulk density depending on the type of treatment and the depth of sampling (Table 2). Bulk density increased with soil depth in many cases irrespective of treatment over the experimental period. Significant differences between treatments were minor in the upper layer in 2014, but significant treatment effect was recorded in the 5-10 cm soil depth as the experimental period progressed from 2014 to 2016 (Table 3). On average, the lowest bulk density $\left(1.14 \mathrm{~g} \mathrm{~cm}^{-3}\right)$ was recorded under biocharamended soils, and the highest was observed under soils with carbon $\left(1.21 \mathrm{~g} \mathrm{~cm}^{-3}\right)$. The results obtained with the straw-amended soils showed a similar trend, except that differences were not significant at $\mathrm{p}<0.05$ in most cases. Saturated hydraulic conductivity (Ksat) was significantly $(\mathrm{p}<0.05)$ affected by carbon, $\mathrm{N}$ fertilizer and year but there was no significant interaction between treatment factors (Table 2). Application of $\mathrm{BN}_{100}$ treatment enhanced mean saturated hydraulic conductivity by $23.7 \%, 24.3 \%$ and $20.4 \%$ relative to $\mathrm{CN}_{0}, \mathrm{CN}_{50}$ and $\mathrm{SN}_{0}$, respectively (Table 4 ). Carbon and year had significant interaction $(\mathrm{p}<0.05)$ on soil organic carbon, except at the $10-30$ $\mathrm{cm}$ soil depth (Table 2). Similarly, carbon and fertilizer-N also interactively affected soil organic $\mathrm{C}$ in all the soil depth evaluated. Application of fertilizer- $\mathrm{N}$ at the 50 and $100 \mathrm{~kg} \mathrm{ha}^{-1}$ rate influenced SOC significantly $(\mathrm{p}<0.05)$ under biochar treated soils, particularly in the depth of $0-5 \mathrm{~cm}$ (Table 5). However, $\mathrm{N}_{100}$ had greater effect compared to $\mathrm{N}_{50}$.

Table 2, 3, 4 and 5: INSERT HERE

\section{Nitrous oxide emissions}

All the treatments were sources of nitrous oxide $\left(\mathrm{N}_{2} \mathrm{O}\right)$ emission throughout the sampling period and the maximum observed $\mathrm{N}_{2} \mathrm{O}$ emissions occurred in early July in each year of this study (Fig.2). These responses were consistent with recorded soil moisture and temperature data. . Significant differences $(\mathrm{p}<0.05)$ were found among treatments at certain periods of measurement (Fig. 3). For example, in 2014, the maximal $\mathrm{N}_{2} \mathrm{O}$ emission of $\mathrm{BN}_{100}$ was $79.5 \mu \mathrm{g} \mathrm{m}^{-2} \mathrm{~h}^{-1}$ and the minimal was $36.5 \mu \mathrm{g} \mathrm{m}^{-2} \mathrm{~h}^{-1}$; they were significantly lower than those for $\mathrm{CN}_{50}\left(100.7 \mu \mathrm{g} \mathrm{m}^{-2} \mathrm{~h}^{-1}\right.$ for maximum and $55.8 \mu \mathrm{g} \mathrm{m}^{-2} \mathrm{~h}^{-1}$ for minimum) and $\mathrm{CN}_{0}\left(98.1 \mu \mathrm{g} \mathrm{m}^{-2} \mathrm{~h}-^{1}\right.$ for maximum and $50.2 \mu \mathrm{g} \mathrm{m}^{-2} \mathrm{~h}^{-1}$ for minimum). At a lesser magnitude, $\mathrm{SN}_{0}$ and $\mathrm{SN}_{50}$ also produced significantly lower $\mathrm{N}_{2} \mathrm{O}$ emission compared to $\mathrm{CN}_{0}$ and $\mathrm{CN}_{50}$. During this period the lowest seasonal $\mathrm{N}_{2} \mathrm{O}$ emission was mostly recorded in the biochar treated soils and at a lesser magnitude in the straw treated soils. 
276

277

278

279

280

281

282

283

284

285

286

287

288

289

290

291

292

293

294

295

296

297

298

299

300

301

302

303

304

305

306

307

308

309

310

311

312

313

314

There were no significant treatment interactions $(\mathrm{p}<0.05)$ effect on cumulative $\mathrm{N}_{2} \mathrm{O}$ emission (Table 6), but treatment factors independently influenced cumulative $\mathrm{N}_{2} \mathrm{O}$ emission. The highest cumulative $\mathrm{N}_{2} \mathrm{O}$ emissions were consistently observed in the fertilized soils compared to the unfertilized soils, but differences were not always significant (Table 6). Application of $\mathrm{BN}_{0}$, $\mathrm{BN}_{50}$ and $\mathrm{BN}_{100}$ significantly decreased cumulative $\mathrm{N}_{2} \mathrm{O}$ emission by $48.42 \%, 37.12 \%$ and $35.80 \%$ on average compared to $\mathrm{CN}_{100}$, respectively (Table 4). The mean cumulative $\mathrm{N}_{2} \mathrm{O}$ emission of biochar was averaged at $1.83 \mathrm{~kg} \mathrm{ha}^{-1}$ representing significant decrease of $10.93 \%$ and $38.61 \%$ compared to straw treated soils $\left(2.03 \mathrm{~kg} \mathrm{ha}^{-1}\right)$ and soils without carbon treatment $\left(2.42 \mathrm{~kg} \mathrm{ha}^{-1}\right)$. Straw treated soils had non-significant cumulative $\mathrm{N}_{2} \mathrm{O}$ decrease of $0.39 \mathrm{~kg} \mathrm{ha}^{-1}$, or $19.40 \%$ less compared to no carbon soils.

Fig. 2 and table 6: INSERT HERE

\section{Methane emissions}

All the treatments had similar trends of seasonal $\mathrm{CH}_{4}$ dynamics and were net carbon sinks over the three study years (Fig.3). The minimum $\mathrm{CH}_{4}$ consumption was recorded in April 2014 and 2015, and in September 2016. In the present study, a single peak was observed in June 2014, whiles double peaks were observed in May and July 2015 and 2016. During this period, the greatest seasonal $\mathrm{CH}_{4}$ consumption of $-79.94,-81.07$ and $-111.59 \mu \mathrm{g} \mathrm{m}^{-2} \mathrm{~h}^{-1}$ in 2014,2015 and 2016 respectively were observed in $\mathrm{BN}_{100}$ soils; it was $38.14 \%, 47.37 \%, 43.05 \%$ more compared to $\mathrm{CN}_{0}$ $\left(-57.87,-55.01\right.$ and $\left.-78.01 \mu \mathrm{g} \mathrm{m}^{-2} \mathrm{~h}^{-1}\right)$. At a lesser extent, the maximum seasonal $\mathrm{CH}_{4}$ consumption in $\mathrm{SN}_{50}$ and $\mathrm{SN}_{100}$ soils were significantly higher $(\mathrm{p}<0.05)$ compared to the $\mathrm{CN}_{0}$ and $\mathrm{CN}_{50}$ soils. The results were clear that, the greater seasonal $\mathrm{CH}_{4}$ consumption occurred with the higher $\mathrm{N}$ fertilizer soils and the greatest $\mathrm{CH}_{4}$ uptake generally occurred in the biochar treated soils, followed by the straw treated soils and the least were observed in the no carbon soils

Year individually had a significant effect $(\mathrm{p}<0.05)$ on cumulative $\mathrm{CH}_{4}$ emission (Table 7), and interaction between carbon and year significantly affected cumulative $\mathrm{CH}_{4}$ emission. The results of cumulative $\mathrm{CH}_{4}$ emission showed that increasing $\mathrm{N}$ fertilizer rates generally enhanced $\mathrm{CH}_{4}$ consumption in all treatments. The use of $\mathrm{BN}_{100}$ boosted cumulative $\mathrm{CH}_{4}$ uptake in 2014 (by $21.9 \%$ and $18.2 \%$ ), 2015 (by $83.6 \%$ and $59.1 \%$ ) and 2016 (by $30.5 \%$ and $18.4 \%$ ) compared to $\mathrm{CN}_{0}$ and $\mathrm{CN}_{50}$, respectively. Increasing the fertilizer rate from $\mathrm{N}_{50}$ to $\mathrm{N}_{100}$ resulted in significantly higher cumulative $\mathrm{CH}_{4}$ consumption $(\mathrm{p}<0.05)$ on straw treated soils in 2014 relative to $\mathrm{N}_{0}$ on soils without carbon; the increase was $16.8 \%$. In 2015, application of $\mathrm{SN}_{100}$ increased cumulative $\mathrm{CH}_{4}$ sink by $41.0 \%, 73.0 \%, 22.8 \%$ and $26.8 \%$ compared with $\mathrm{CN}_{0}, \mathrm{CN}_{50}$ and $\mathrm{CN}_{100}$, respectively. The mean cumulative $\mathrm{CH}_{4}$ consumption was greatest in biochar treated plots $\left(-2.8 \mathrm{~kg} \mathrm{ha}^{-1}\right)$, followed by straw treated soils $\left(-2.6 \mathrm{~kg} \mathrm{ha}^{-1}\right)$ and the least in no carbon soils $\left(-2.3 \mathrm{~kg} \mathrm{ha}^{-1}\right)$.

Table 7 and Fig.3: INSERT HERE 


\section{Biomass and grain yield}

318

319

320

321

322

323

324

325

326

327

328

329

330

331

332

333

334

335

336

337

338

339

340

341

342

343

344

345

346

347

348

349

350

351

352

353

354

There was significant interaction effects between carbon and nitrogen, and nitrogen and year on biomass yield at $\mathrm{p}<0.05$ (Table 2). In addition, carbon, nitrogen and year individually had significant effect on biomass yield. Application of $\mathrm{N}_{100}$ treatments on biochar treated soils $\left(\mathrm{BN}_{100}\right)$ increased biomass yield by $39.05 \%$ in $2014,37.31 \%$ in 2015 and $30.02 \%$ in 2016 on average compared to soils without carbon (Table 8). Similarly, $\mathrm{BN}_{100}$ significantly increased biomass yield in 2014 (by $35.06 \%$ and 26.43\%), 2015 (by $40.04 \%$ and $23.11 \%$ ) and 2016 (by $21.86 \%$ and 13.45\%) compared to $\mathrm{SN}_{0}$ and $\mathrm{SN}_{50}$ sites, respectively. Application of $\mathrm{SN}_{100}$ also caused significant increases in biomass yield compared to no carbon soils, an average increase of $32.09 \%$, $29.32 \%$ and $32.56 \%$ were recorded in 2014, 2015 and 2016 respectively. The grain yield under $\mathrm{N}_{100}$ fertilization was significantly increased $(\mathrm{p}<0.05)$ by $35.87 \%, 29.45 \%$ and $13.34 \%$ under no carbon soils; $33.64 \%, 37.02 \%$ and $39.16 \%$ under biochar soils, and $31.89 \%, 32.35 \%$ and $24.08 \%$ under biomass treated soils in 2014, 2015 and 2016, respectively, compared to their corresponding $\mathrm{N}_{0}$ soils (Table 7)..

Table 5 and 6: INSERT HERE

\section{Discussion}

The lowest cumulative $\mathrm{N}_{2} \mathrm{O}$ emission was recorded in the biochar treated soils and at a lesser magnitude in the straw treated soils, whereas the highest $\mathrm{N}_{2} \mathrm{O}$ emission was observed in the no carbon treated soils. In both cases, the highest rate of $\mathrm{N}$ fertilizer recorded the greatest $\mathrm{N}_{2} \mathrm{O}$ emission. Contrary, Chatskikh and Olesen (2007) and Kammann et al. (2012) reported that $\mathrm{N}_{2} \mathrm{O}$ fluxes were significantly increased by addition of biochar, particularly when added with mineral $\mathrm{N}$-fertilizer. It has been shown that the type and rate of fertilizer have an important impact on $\mathrm{N}_{2} \mathrm{O}$ emissions (Bouwman et al., 2002). Some studies have reported that use of crop straw combined with mineral nitrogen fertilizer enhances soil quality while reducing $\mathrm{N}_{2} \mathrm{O}$ emissions (Xu et al., 2019; Sainju et al., 2016). Crop straw return commonly aims at improving soil carbon and nitrogen cycling (Xu et al., 2019; Meng et al., 2017), thought it can also be a source of trace gas emissions (Cha et al., 2016). Nitrogen fertilization has the greatest potential to increase $\mathrm{N}_{2} \mathrm{O}$ emissions because mineral $\mathrm{N}$ controls both nitrification and denitrification. Other studies (Zhang et al., 2011) have shown that biochar combined with $\mathrm{N}$-fertilizer can significantly reduce $\mathrm{N}_{2} \mathrm{O}$ emissions. One mechanism that may explain lower (cumulative) $\mathrm{N}_{2} \mathrm{O}$ fluxes from biochar + $\mathrm{N}$-fertilizer-amended soils is the fact that relatively low $\mathrm{C}$ soils treated with $\mathrm{N}$-fertilizer and biochar may retain relatively higher amounts of mineral $\mathrm{N}$ than soils untreated with $\mathrm{N}$-fertilizer (Zhang et al., 2011). Nitrogen thereby retained provides a source of available $\mathrm{N}$ for plant uptake, which reduces $\mathrm{N}$ availability for microbes involved in denitrification processes. Since biochar has significant impact on soil environment and affects many soil parameters such as the availability of substrates (Van Zwieten et al., 2009), it is very likely that biochar will have significant effects on the production of $\mathrm{N}_{2} \mathrm{O}$. Their results is confirmed by the increased plant $\mathrm{N}$

Peerj reviewing PDF | (2021:01:57597:2:0:NEW 3 Jul 2021) 
355

356

357

358

359

360

361

362

363

364

365

366

367

368

369

370

371

372

373

374

375

376

377

378

379

380

381

382

383

384

385

386

387

388

389

390

391

392

393

394

uptake in this study (Table S4). Singh et al. (2010) reported that biochar can also reduce the N availability to microorganisms by absorption. In this study, improved soil porosity could also explain the decreased $\mathrm{N}_{2} \mathrm{O}$ emission recorded when biochar was applied with $\mathrm{N}$ fertilizer. Soil aeration and improved porosity inhibit denitrification. Nitrogen dynamics are affected by changes in soil aeration, $\mathrm{pH}$ and the $\mathrm{C} / \mathrm{N}$ ratio of the material incorporated into the soil. Biochar may suppress $\mathrm{N}_{2} \mathrm{O}$ production from denitrification by increasing the air content of the soil or by absorbing water from the soil, thus improving aeration of the soil (Yanai et al., 2007). Karhu et al. (2011) shared similar view and observed that biochar amendment modifies soil physical properties such as reducing soil bulk density or increasing water holding capacity (Karhu et al., 2011 ), thereby increasing soil aeration. This may lead to lower soil $\mathrm{N}_{2} \mathrm{O}$ emissions, as soil aeration influences both nitrifier and denitrifier activity. Soils, which are not affected by compaction often exhibit adequate porosity and therefore the risk of denitrification is lower compared with soils that have impaired infiltration or internal drainage (Antille et al., $2015 \mathrm{In}$ this study, lower $\mathrm{N}_{2} \mathrm{O}$ emissions were also observed on the straw treated plots, although the effects were lesser relative to the biochar treated soils. The lower $\mathrm{N}_{2} \mathrm{O}$ emission under straw treated soils could be attributed to the accumulation of organic matter on the soil surface that led to reduced bulk density and thus improved soil aeration.

Reductions in $\mathrm{CH}_{4}$ emission were observed in biochar-amended soils and to a lesser extent on straw amended soils compared to their controls. Literature evidence indicated that biochar input to soil can potentially reduce $\mathrm{CH}_{4}$ emissions (Yeboah et al., 2018). In contrast, Xie et al. (2020) showed that charcoal input into soil may increase soil methane fluxes. The mechanisms underlying changes in soil $\mathrm{CH}_{4}$ emissions following biochar amendment are unclear (Lehmann et al., 2011). The greater uptake of $\mathrm{CH}_{4}$ may be attributed to the protected environment created for the $\mathrm{CH}_{4}$ oxidizers and improved soil porosity. In this study, the greater uptake of methane in the soils with carbon amendment, particularly biochar amended soils with $\mathrm{N}$ fertilizer may be attributed to the favorable environment created for the $\mathrm{CH}_{4}$ oxidizers. The aerobic, well drained soils can be a sink for $\mathrm{CH}_{4}$ due to the possible high rate of $\mathrm{CH}_{4}$ diffusion and ensuing oxidation by methanotrophs. Combined application of biochar and inorganic $\mathrm{N}$-fertilizer in this study improved soil physical properties (reduction in soil bulk density and increased soil saturated hydraulic conductivity) . Such improved soil structural conditions are known to protect the ecological niche for methanotrophic bacteria, influence the gaseous diffusivity, and affect the rate of supply of atmospheric $\mathrm{CH}_{4}$ (Hütsch 1998; Serrano-Silva et al., 2014; Ma et al., 2016). Aerobic, welldrained soils behave as a sink for $\mathrm{CH}_{4}$ due to the high rates of $\mathrm{CH}_{4}$ diffusion and subsequent oxidation by methanotrophs (Serrano-Silva et al., 2014). However, these results do not appear to support the conclusions of Laird et al. (2008) on the reduction observed in methane emissions from field plots, which was deduced as an increased $\mathrm{CH}_{4}$ oxidation activity. Other studies have reported significant increase in $\mathrm{CH}_{4}$ emissions following biochar or biomass application (e.g., Wang et al., 2012). The authors explained that, the increased availability of labile $\mathrm{C}$ substrates following biochar or biomass addition stimulates the activities of methanogenic bacteria which may account for increased $\mathrm{CH}_{4}$ emissions. However, this could be a short-term effect since labile carbon fraction 
395

396

397

398

399

400

401

402

403

404

405

406

407

408

409

410

411

412

413

414

415

416

417

418

419

420

421

422

423

424

425

426

427

428

429

430

431

432

433

434

in the materials could be mineralized rapidly (Wang et al., 2012).

The results of this study indicate that when biochar was applied together with fertilizer N, both biomass and grain yield of spring wheat increased. This finding shows the potential of biochar applied together with fertilizer $\mathrm{N}$ to improve nutrient use efficiency in spring wheat in semiarid environment (Solaiman et al., 2010). Diverse reasons have been given to the positive effect of biochar applied in combination with fertilizer N on crop yield. Brunn et al. (2011) reported that combined application of biochar and $\mathrm{N}$ fertilizer has the potential to improve soil properties and could therefore be responsible for the effect observed. Similarly, both Borchard et al. (2012) and Tammeorg et al. (2014) attribute increased crop productivity when biochar is applied together with $\mathrm{N}$ fertilizer to improve nutrient availability. In the current study, increased yield may be attributed to increased nutrient availability and improved soil physical and chemical properties (soil bulk density, saturated hydraulic conductivity and soil organic carbon), also reported in earlier work (Zhang et al. 2010). These results imply that, when biochar and inorganic fertilizers are applied together, an increased nutrient supply to plants may be the most important factor in increasing crop yields. The higher biomass and grain yield obtained on the carbon amended soils compared to the soils without carbon in this study is attributed to the fact that in drier soils,crop residues provide a better soil environment by reducing temperature, conserving water, and improving soil quality resulting in better yield (Zou et al., 2016). Positive effects of biochar combined with $\mathrm{N}$ fertilizer on increasing SOC and hydraulic conductivity as well as decreasing soil bulk density was observed in this study. Therefore, this study evidenced a positive effect of biochar amendment on soil quality and spring wheat yield consistent over three consecutive years. Furthermore, the lowest yield recorded on the no carbon soils throughout this study may be related to the removal of all the aboveground biomass at the end of the cropping season. Zhang et al. (2008) showed that field practices with low carbon inputs to arable soils as crop biomass removal and manure abandonment deplete soil organic carbon and reduce crop productivity. Therefore, when biochar was applied and crop residues retained, it had immediate effect and the beneficial influence on biomass and grain yields were obtained.

\section{Conclusions}

Application of crop residue amendments combined with nitrogen fertilizer has been increasingly recommended as an effective management practice for mitigating greenhouse gas emissions while enhancing soil fertility, thereby increasing crop production. In this paper, we have shown that application of carbon amendment, especially biochar combined with $\mathrm{N}$ fertilizer in wheat grown under rain fed conditions in a semi-arid environment reduced nitrous oxide and methane emissions whilst increasing biomass and grain yield. This study confirmed our hypothesis that increased $\mathrm{C}$ inputs would increase the soils ability to reduce $\mathrm{N}_{2} \mathrm{O}$ and $\mathrm{CH}_{4}$ soil emissions whiles increasing biomass and grain yield. The main conclusions derived from this work are: application of biochar $+\mathrm{N}$-fertilizer $\left(\mathrm{BN}_{100}\right)$ or straw $+\mathrm{N}$-fertilizer $\left(\mathrm{SN}_{100}\right)$ increased saturated hydraulic conductivity to significantly greater extent than the other treatments tested. This translated into higher biomass production and therefore grain yield in those treatments. These 
435 results indicate the dependency of crop yield on soil quality and imply that crop productivity 436 could be increased without resource degradation when biochar is applied combined with $\mathrm{N}$ 437 fertilizer. Application of biochar $+\mathrm{N}$-fertilizer showed relatively lower $\mathrm{N}_{2} \mathrm{O}$ emissions, including 438 increased uptake of $\mathrm{CH}_{4}$, but the effect of $\mathrm{BN}_{100}$ was consistently greater. The findings of this 439 study suggest that biochar applied together with $\mathrm{N}$-fertilizer can concurrently improve soil 440 physical and chemical properties as well as biomass and grain yield while reducing the effect of

441

442

443

444

445

446

447

448

449

450

451

452

453

454

455

456

457

458

459

460

461

462

463

464

465

466

467

468

469

470

471

472

agricultural activities on the environment. Based on this results, the potential exist for developing crop and soil management interventions around biochar applied together with fertilizer $\mathrm{N}$ in semiarid environments. Further studies that focus on $\mathrm{N}_{2} \mathrm{O}$ and $\mathrm{CH}_{4}$ measurements after every rainfall, tillage and fertilization events are required for better recommendations.

\section{Acknowledgements}

Our thanks go to Gansu Agricultural University for the assistance in the present work and students and supervisors of Gansu Provincial Laboratory for assistance in laboratory analyses.

\section{References}

Antille, D L (2018) Evaluation of fertigation applied to furrow and overhead irrigated cotton grown in a Black Vertosol in Southern Queensland, Australia. Applied Engineering in Agriculture 34(1): 197-211. doi: 10.13031/aea.12519

Bruun EW, Muller-Stover D, Ambus P, Hauggaard-Nielsen H (2011) Application of biochar to soil and $\mathrm{N}_{2} \mathrm{O}$ emissions: potential effects of blending fast-pyrolysis biochar with anaerobically digested slurry. Euro Jour Soil Sci, 62: 581-589. doi: 10.1111/j.13652389.2011.01377

Borchard N A, Wolf V, Laabs R, Aeckersberg HW, Scherer A, Moeller W, Amelung (2012) Physical activation of biochar and its meaning for soil fertility and nutrient leaching-a greenhouse experiment. Soil Use Manage 28:177-184

Bouwman AF, Boumans LJM, Batjes NH (2002) Emissions of $\mathrm{N}_{2} \mathrm{O}$ and $\mathrm{NO}_{2}$ from fertilized fields: Summary of available measurement data. Glob Biogeo Cycles, 16. doi: 10.1029/2001GB001811.

Carter MR (1993) Soil sampling and methods of analysis, Canadian Society of Soil Science, Lewis Publisher London 823

Cayuela ML, Oenema O, Kuikman PJ, Bakker RR, Van Groenigen JW (2010). Bioenergy byproducts as soil amendments? Implications for carbon sequestration and greenhouse gas emissions. Glob Ch Biol Bio 2: 201-213

Cha J S; Park S H, Jung S C, Ryu C, Jeon J K., Shin M C, Park Y K 2016. Production and utilization of biochar: A review. J. Ind. Eng. Chem 40: 1-15.

Chatskikh D, Olesen JE (2007) Soil tillage enhanced $\mathrm{CO}_{2}$ and $\mathrm{N}_{2} \mathrm{O}$ emissions from loamy sand soil under spring barley. Soil and Till Res 97: 5-18 
473

474

475

476

477

478

479

480

481

482

483

484

485

486

487

488

489

490

491

492

493

494

495

496

497

498

499

500

501

502

503

504

505

506

507

508

509

510

511

Chinese Soil Taxonomy Cooperative Research Group (1995) Chinese Soil Taxonomy (Revised Proposal). Institute of Soil Science/Chinese Agricultural Science and Technology Press, Academic Sinica/Beijing

Clough TJ, Condron LM, Kammann C, Müller C (2013) A review of biochar and soil nitrogen dynamics. Agrono 3, 275-293; doi: 10.3390/agronomy3020275. ISSN 2073-4395. www.mdpi.com/journal/agronomy.

FAO (1990) Soil map of the world: revised legend. World Soil Resources Report 60. Food and Agriculture Organization of the United Nations, Rome

Grace P (2016) Foreword. Soil Research, 54(5): i-ii. http://dx.doi.org/10.1071/SRv54n5_FO

He L, Cleverly J, Chen C, Yang, X, Li J, Liu W, Yu Q, (2014) Diverse responses of winter wheat yield and water use to climate change and variability on the semiarid Loess Plateau in China. 2003. Agron. J. 106:1169-1178. doi:10.2134/agronj13.0321

Huang JP, Ma JR, Guan XD, Li Y, He Y.L (2019) Progress in semi-arid climate change studies in China. Adv. Atmos. Sci 36 (9): 922-937, https://doi.org/10.1007/s00376-018-8200-9.

Hütsch BW (1998) Tillage and land use effects on methane oxidation rates and their vertical profi les in soil. Biol. Fertil. Soils. 27, 284-292

IPCC (2014) Climate Change: Mitigation of Climate Change. Intergovernmental Panel on Climate Change, Internet: http://www.ipcc.ch/report/ar5/wg3/

Kammann C, Ratering S, Eckhard C, Müller C (2012) Biochar and hydrochar effects on greenhouse gas (carbon dioxide, nitrous oxide, and methane) fluxes from soils. J. Environ. Qual. 41:1052-1066

Knoblauch C, Maarifat AA, Pfei_er, EM, Haefele S (2011) Degradability of black carbon and its impact on trace gas fluxes and carbon turnover in paddy soils. Soil Boil. Biochem 43:1768-1778.

Laird D, Fleming P, Wang B, Horton R, Karlen D (2010) Biochar impact on nutrient leaching from a Midwestern agricultural soil. Geoderma 158: 436-444

Lehmann J, Rillig MC, Thies J, Masiello CA, Hockaday WC, Crowley D (2011) Biochar effects on soil biota -a review. Soil Biol. Biochem 43:1812-1836.

Liu QF, Chen Y, Li WW, Liu Y, Han J, Wen XX, Liao YC (2016) Plastic-film mulching and urea types a_ect soil $\mathrm{CO}_{2}$ emissions and grain yield in spring maize on the Loess Plateau, China. Sci. Rep, 6:1-10.

Ma N, Zhang L, Zhang Y, Yang L, Yu C, Yin G, Timothy Doane A, Wu Z, Zhu P, Ma X (2016) Biochar Improves Soil Aggregate Stability and Water Availability in a Mollisol after Three Years of Field Application. PLoS ONE 11(5):e0154091. doi:10.1371/journal.pone.0154091

Meng F, Dungait J A, Xu X., Bol R, Zhang X., Wu W (2017) Coupled incorporation of maize (Zea mays L.) straw with nitrogen fertilizer increased soil organic carbon in Fluvic Cambisol. Geoderma, 304, 19-27.

PeerJ reviewing PDF | (2021:01:57597:2:0:NEW 3 Jul 2021) 
512 Nelson DW, Sommers LW (1982) Total carbon, organic carbon and organic matter. In: Page AL,

513

514

515

516

517

518

519

520

521

522

523

524

525

526

527

528

529

530

531

532

533

534

535

536

537

538

539

540

541

542

543

544

545

546

547

548

549

550

551 Miller RH, Keeney DR (eds.) Methods of soil analysis Part 2. Second edition. Chemical and microbiological properties. J Am Soc Agron and Soil Sci Soc Am J, Madison, Wisconsin USA, 301-312.

Norton R (2014) Combating climate change through improved agronomic practices and input-use efficiency. J of Crop Improve. 28(5): 575-618. doi: 10.1080/15427528.2014.924331

Rivka BF, David AL, Timothy BP (2019) Effect of Biochar on Soil Greenhouse Gas Emissions at the Laboratory and Field Scales. Soil Syst. 3 (8) 2-18 doi:10.3390/soilsystems3010008.

Saggar S (2010). Estimation of nitrous oxide emission from ecosystems and its mitigation technologies. Agriculture Ecosystem Environment, 136:189-191. doi:10.1016/j.agee.2010.01.007

Sainju UMA (2016). Global Meta-Analysis on the Impact of Management Practices on Net Global Warming Potential and Greenhouse Gas Intensity from Cropland Soils. PLoS ONE.

Serrano-Silva N, Sarria-Guzman Y, Dendooven L, Luna-Guido M (2014) Methanogenesis and methanotrophy in soil: a review. Pedosphere 24(3): 291-307. doi:10.1016/S10020160(14)60016-3.

Shirley Lamptey, Lingling Li, Junhong Xie (2018). Impact of nitrogen fertilization on soil respiration and net ecosystem production in maize. Plant Soil Environ. https://doi.org/10.17221/217/2018-PSE

Singh BP, Hatton BJ, Singh B, Cowie AL, Kathuria A (2010) Influence of biochars on nitrous oxide

Solaiman ZM, Blackwell P, Abbott LK, Storer P (2010) Direct and residual e $\square$ ect of biochar application on mycorrhizal root colonisation, growth and nutrition of wheat. Soil Res. 48: $546-554$

Solomon S, Qin DM, Manning Z, Chen M, Marquis KB, Averyt M, Tignor, Miller HL (2007) "Technical Summary." in Climate Change 2007: The Physical Science Basis, Contribution ofWorking Group I to the Fourth Assessment Report of the Intergovernmental Panel on Climate Change. Cambridge University Press, Cambridge, United Kingdom and New York, NY, USA. http://www.ipcc.ch.

Tullberg J, Antille DL, Bluetta C, Eberhard J, Scheer C (2018) Controlled traffic farming effects on soil emissions of nitrous oxide and methane. Soil \& Till Res. 1-9

van Zwieten L, Bhupinderpal-Singh, Joseph S, Kimber S, Cowie A, Chan Y (2009) Biochar reduces emissions of non-CO2 GHG from soil. In 'Biochar for environmental management'. (Eds J Lehmann, S Joseph). Earthscan Publications Ltd: London, 227-249.

Walkley AJ, Black, IA (1934) Estimation of soil organic carbon by the chromic acid titration method. Soil Sci. 37: 29-38. 
552 Wang J, Xie J, Li L, Luo Z, Zhang R, Wang L and Jiang Y (2021) The Impact of Fertilizer

553

554

555

556

557

558

559

560

561

562

563

564

565

566

567

568

569

570

571

572

573

574

575

576

577

578

579

580

581

582

583

584

585

586

587

588

589

590

591

Amendments on Soil Autotrophic Bacteria and Carbon Emissions in Maize Field on the Semiarid Loess Plateau. Front. Microbiol. 12:664120. doi: 10.3389/fmicb.2021.664120

Wang W, Peng SS, Wang T, Fang JY (2010) Winter soil $\mathrm{CO}_{2}$ efflux and its contribution to annual soil respiration in different ecosystems of a forest-steppe ecotone, North China

Woolf D, Amonette JE, Street-Perrott FA, Lehmann J, Joseph S (2010) Sustainable biochar to mitigate global climate change. Nat Commun. 1:1-9. doi:10.1038/ncomms1053

Xie, Z, Xu Y, Liu G, Liu Q, Zhu J, Tu C, Amonette J E, Cadisch J W Y, Hu S (2021) Impact of biochar application on nitrogen nutrition of rice, greenhouse-gas emissions and soil organic carbon dynamics in two paddy soils of China. Plant Soil 370: 527-540

Xu Z F, Yang, Z L (2017) Relative impacts of increased greenhouse gas concentrations and land cover change on the surface climate in arid and semi-arid regions of China. Clim Change, 144: 491-503, https://doi.org/10.1007/s10584-017-2025-x

Xu C, Han X, Ru S (2019). Cardenas, L.; Rees, R.M.; Wu, D.; Wu, W.; Meng, F. Crop straw incorporation interacts with $\mathrm{N}$ fertilizer on $\mathrm{N} 2 \mathrm{O}$ emissions in an intensively cropped farmland. Geoderma 341: 129-137

Yanai Y, Toyota K, Okazaki M (2007) Effect of charcoal addition on $\mathrm{N} 2 \mathrm{O}$ emissions from soil resulting from rewetting air-dried soil in short-term laboratory experiments. Soil Science and Plant Nutrition, 53:181-188

Yeboah S, Lamptey S, Cai L, Song M (2018) Short-Term Effects of Biochar Amendment on Greenhouse Gas Emissions from Rainfed Agricultural Soils of the Semi-Arid Loess Plateau Region. Agronomy 8 (74); doi:10.3390/agronomy8050074.

Yeboah S, Zhang R, Cai L, Song M, Li L, Xie, Luo Z, Wu J, Zhang J (2016) Greenhouse gas emissions in a spring wheat-field pea sequence under different tillage practices in semiarid Northwest China. Nutr Cycl Agroecosyst 106: 77-91.doi: 10.1007/s10705-016-9790

Zhang YT, Guan X D, Yu PY, Xie KY, Jin CH (2017) Contributions of radiative factors to enhanced dryland warming over East Asia. J. Geophys. Res., 122, 7723-7736, https://doi.org/10.1002/2017JD026506.

Zhang A, Cui L, Pan G, Li L, Hussain Q, Zhang X, Zheng J, Crowley D (2010) Effect of biochar amendment on yield and methane and nitrous oxide emissions from a rice paddy from Tai Lake plain, China. Agric Ecosyst Environ 139:469-475

Zhang A, Liu Y, Pan G, Hussain Q, Li L, Zheng J, Zhang X. (2011) Effect of biochar amendment on maize yield and greenhouse gas emissions from a soil organic carbon poor calcareous loamy soil from Central China Plain. Plant Soil, 139: 469-475. doi:10.1007/s11104-0110957

Zhu Z, Ge T, Luo Y, Liu S, Xu X, Tong C, Shibistova O, Guggenberger G, Wu J (2018) Microbial stoichiometric flexibility regulates rice straw mineralization and its priming effect in paddy soil. Soil Boil. Biochem. 121: 67-76

Peer] reviewing PDF | (2021:01:57597:2:0:NEW 3 Jul 2021) 
592 Zimmerman AR, Gao B, Ahn MY (2011) Positive and negative carbon mineralization priming 593 effects among a variety of biochar-amended soils. Soil Boil. Biochem 43: 1169-1179

594

595

Zou H, Ye X, Li J, Lu J, Fan Q, Yu N (2016) Effects of straw return in deep soils with urea addition on the soil organic carbon fractions in a semi-arid temperate cornfield. PLOS ONE, 11

596 (4): e0153214. doi:10.1371/journal.pone.0153214.

597

598

Zou J, Huang Y, Jiang J, Zheng X, Sass RL. (2005) A 3-year field measurement of methane and 599 nitrous oxide emissions from rice paddies in China: Effects of water regime, crop residue, 600 and fertilizer application. Glob. Bio. Cycles, 19 


\section{Table 1 (on next page)}

Characterization of biochar and straw used in the study

Values are means for $n=2$. 


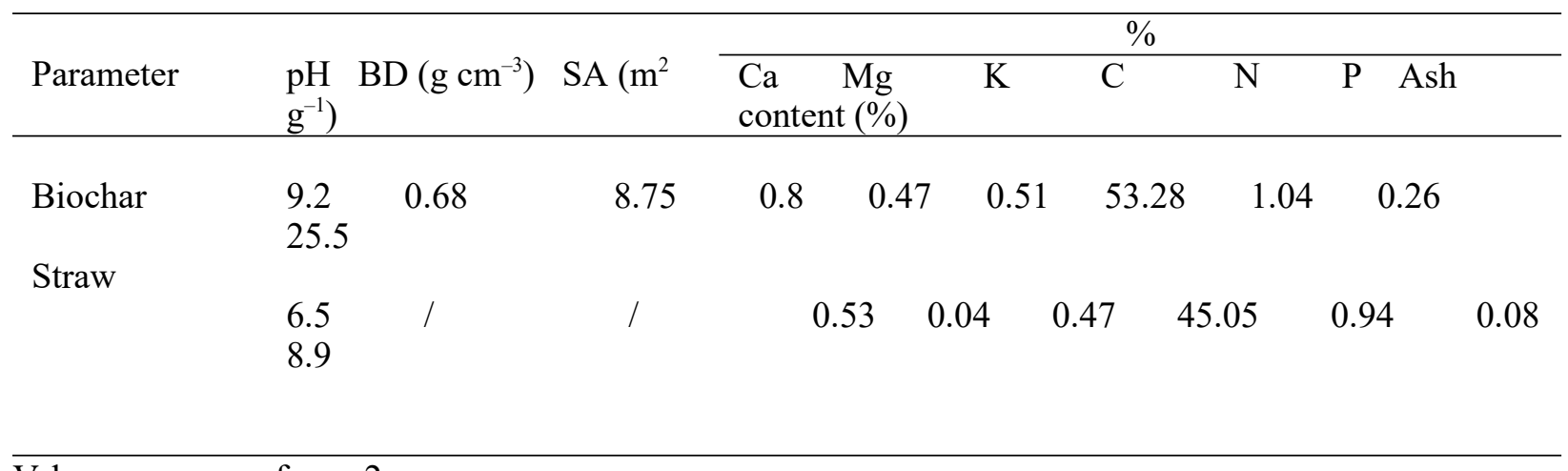

Values are means for $n=2$. 
Table 2 (on next page)

Analysis of variance for carbon, nitrogen and year effects and their interaction 
1

\begin{tabular}{|c|c|c|c|c|c|c|c|c|c|c|}
\hline \multirow[t]{2}{*}{ Sources } & \multicolumn{2}{|c|}{$\begin{array}{c}\text { Soil bulk } \\
\text { density }\end{array}$} & \multirow[b]{2}{*}{$\begin{array}{l}\text { Ksa } \\
\mathrm{t}\end{array}$} & \multicolumn{3}{|c|}{ Soil organic carbon } & \multirow[b]{2}{*}{$\begin{array}{l}\mathrm{N}_{2} \\
\mathrm{O}\end{array}$} & \multirow[b]{2}{*}{$\mathrm{CH}_{4}$} & \multirow[b]{2}{*}{$\begin{array}{l}\text { Biomass } \\
\text { yield }\end{array}$} & \multirow[b]{2}{*}{$\begin{array}{l}\text { Grain } \\
\text { yield }\end{array}$} \\
\hline & $0-5$ & $5-10$ & & $\begin{array}{l}0- \\
5\end{array}$ & $\begin{array}{l}5- \\
10\end{array}$ & $\begin{array}{l}10- \\
30\end{array}$ & & & & \\
\hline Carbon (C) & $* *$ & $*$ & $*$ & $*$ & $*$ & n.s. & $* *$ & n.s. & $* *$ & $* *$ \\
\hline $\begin{array}{l}\text { Nitrogen } \\
(\mathrm{N})\end{array}$ & $* *$ & n.s. & $*$ & $* *$ & $*$ & n.s. & $* *$ & n.s. & $* *$ & $* *$ \\
\hline Year (Y) & n.s. & $*$ & $*$ & $*$ & n.s. & n.s. & $*$ & $* *$ & $*$ & $* *$ \\
\hline $\mathrm{C} \times \mathrm{N}$ & n.s. & n.s. & n.s. & n.s. & n.s. & n.s. & n.s. & $*$ & $*$ & n.s \\
\hline $\mathrm{C} \times \mathrm{Y}$ & n.s. & n.s. & n.s. & $* *$ & $* *$ & n.s. & n.s. & $* *$ & n.s & n.s \\
\hline $\mathrm{N} \times \mathrm{Y}$ & n.s. & n.s. & n.s. & n.s. & n.s. & n.s. & n.s. & n.s. & n.s & $* *$ \\
\hline
\end{tabular}

$2 *$, ** indicate significant difference at $\mathrm{p}_{\mathrm{p}}<0.05$ and $\mathrm{p}<0.01$, respectively. n.s. indicate no

3 significance difference at ${ }_{\mathrm{P}}<0.05$.

4

5 


\section{Table 3(on next page)}

Soil bulk density as affected by carbon addition sources 
2

3

\begin{tabular}{|c|c|c|c|c|c|c|c|}
\hline \multicolumn{2}{|c|}{ Treatment } & \multicolumn{6}{|c|}{ Soil BD $\left(\mathrm{g} \mathrm{cm}^{-3}\right)$} \\
\hline \multirow[t]{3}{*}{ C source } & \multirow[t]{3}{*}{ Mineral N } & $0-5$ & \multicolumn{4}{|l|}{$5-10$} & \multirow{2}{*}{$10-30$} \\
\hline & & \multicolumn{5}{|c|}{. } & \\
\hline & & Mean & 2014 & 2015 & 2016 & Mean & Mean \\
\hline \multirow[t]{3}{*}{ No carbon } & $\mathrm{N}_{0}$ & $1.24 \mathrm{a}$ & $1.32 \mathrm{a}$ & $1.30 \mathrm{ab}$ & $1.27 \mathrm{a}$ & $1.29 \mathrm{a}$ & $1.29 \mathrm{a}$ \\
\hline & $\mathrm{N}_{50}$ & $1.17 \mathrm{bc}$ & $1.24 \mathrm{a}$ & $1.25 \mathrm{abc}$ & $1.17 \mathrm{bc}$ & $1.22 \mathrm{abc}$ & $1.24 \mathrm{a}$ \\
\hline & $\mathrm{N}_{100}$ & $1.20 \mathrm{ab}$ & $1.20 \mathrm{a}$ & $1.17 \mathrm{~cd}$ & $1.12 \mathrm{c}$ & $1.16 \mathrm{bc}$ & $1.27 \mathrm{a}$ \\
\hline \multirow[t]{3}{*}{ Biochar } & $\mathrm{N}_{0}$ & $1.17 \mathrm{bc}$ & $1.25 \mathrm{a}$ & $1.25 \mathrm{abc}$ & $1.24 \mathrm{ab}$ & $1.25 \mathrm{abc}$ & $1.27 \mathrm{a}$ \\
\hline & $\mathrm{N}_{50}$ & $1.13 \mathrm{~cd}$ & $1.24 \mathrm{a}$ & $1.16 \mathrm{~cd}$ & $1.14 \mathrm{c}$ & $1.18 b c$ & $1.24 \mathrm{a}$ \\
\hline & $\mathrm{N}_{100}$ & $1.15 \mathrm{bcd}$ & $1.21 \mathrm{a}$ & $1.18 \mathrm{bcd}$ & $1.17 \mathrm{bc}$ & $1.19 b c$ & $1.27 \mathrm{a}$ \\
\hline \multirow[t]{3}{*}{ Straw } & $\mathrm{N}_{0}$ & $1.21 \mathrm{ab}$ & $1.22 \mathrm{a}$ & $1.32 \mathrm{a}$ & $1.23 \mathrm{ab}$ & $1.25 \mathrm{ab}$ & $1.29 \mathrm{a}$ \\
\hline & $\mathrm{N}_{50}$ & $1.11 \mathrm{~d}$ & $1.24 \mathrm{a}$ & $1.08 \mathrm{~d}$ & $1.14 \mathrm{c}$ & $1.16 \mathrm{c}$ & $1.21 \mathrm{a}$ \\
\hline & $\mathrm{N}_{100}$ & $1.14 \mathrm{~cd}$ & $1.28 \mathrm{a}$ & $1.18 \mathrm{~cd}$ & $1.16 \mathrm{bc}$ & $1.21 \mathrm{abc}$ & $1.25 \mathrm{a}$ \\
\hline
\end{tabular}

4 Values with different letters within a column are significantly different at $P<0.05$

5 
Table 4 (on next page)

Saturated hydraulic conductivity as affected by carbon addition sources 
2

\begin{tabular}{llllll}
\hline \multicolumn{2}{c}{ Treatment } & \multicolumn{4}{l}{ Saturated hydraulic conductivity $\left(\mathrm{mm} \mathrm{h}^{-1}\right)$} \\
\cline { 3 - 6 } C source & Mineral N & 2014 & 2015 & 2016 & mean \\
\hline No carbon & $\mathrm{N}_{0}$ & $62.64 \mathrm{~b}$ & $68.86 \mathrm{~b}$ & $62.95 \mathrm{c}$ & $64.82 \mathrm{c}$ \\
& $\mathrm{N}_{50}$ & $65.77 \mathrm{ab}$ & $64.06 \mathrm{~b}$ & $63.71 \mathrm{c}$ & $64.51 \mathrm{c}$ \\
& $\mathrm{N}_{100}$ & $67.63 \mathrm{ab}$ & $60.58 \mathrm{~b}$ & $75.45 \mathrm{abc}$ & $67.89 \mathrm{ab}$ \\
\multirow{3}{*}{ Biochar } & & & & \\
& $\mathrm{N}_{0}$ & $71.93 \mathrm{ab}$ & $62.88 \mathrm{~b}$ & $68.07 \mathrm{bc}$ & $67.63 \mathrm{ab}$ \\
& $\mathrm{N}_{50}$ & $80.49 \mathrm{a}$ & $70.94 \mathrm{ab}$ & $78.98 \mathrm{ab}$ & $76.80 \mathrm{ab}$ \\
& $\mathrm{N}_{100}$ & $78.78 \mathrm{ab}$ & $78.99 \mathrm{a}$ & $82.79 \mathrm{a}$ & $80.19 \mathrm{a}$ \\
& & & & \\
& $\mathrm{N}_{0}$ & $68.66 \mathrm{ab}$ & $65.65 \mathrm{~b}$ & $65.42 \mathrm{c}$ & $66.58 \mathrm{bc}$ \\
& $\mathrm{N}_{50}$ & $76.07 \mathrm{ab}$ & $66.02 \mathrm{~b}$ & $74.75 \mathrm{abc}$ & $72.28 \mathrm{ab}$ \\
& $\mathrm{N}_{100}$ & $75.65 \mathrm{ab}$ & $72.44 \mathrm{ab}$ & $71.24 \mathrm{abc}$ & $73.11 \mathrm{ab}$ \\
\hline
\end{tabular}

3 Values with different letters within a column are significantly different at $P<0.05$. $\mathrm{n}=3$

4 
Table 5 (on next page)

Soil organic carbon as affected by different treatments 
2

\begin{tabular}{|c|c|c|c|c|c|c|c|c|c|}
\hline \multicolumn{2}{|c|}{ Treatment } & \multicolumn{8}{|c|}{ Soil organic $\mathrm{C}\left(\mathrm{g} \mathrm{kg}^{-1}\right)$} \\
\hline \multirow[t]{2}{*}{ C source } & \multirow[t]{2}{*}{$\mathrm{N}$ rate } & \multicolumn{4}{|l|}{$0-10$} & \multicolumn{4}{|l|}{$10-30$} \\
\hline & & 2014 & 2015 & 2016 & Mean & 2014 & 2015 & 2016 & Mean \\
\hline \multirow[t]{3}{*}{ No carbon } & $\mathrm{N}_{0}$ & $9.64 c$ & $9.86 c$ & $10.43 e$ & $9.98 d$ & $9.29 b$ & $9.58 b$ & $9.48 \mathrm{e}$ & $9.45 c$ \\
\hline & $\mathrm{N}_{50}$ & $10.18 \mathrm{bc}$ & $9.92 b c$ & $11.54 d$ & $10.55 \mathrm{~cd}$ & $10.34 a b$ & $9.73 b$ & $10.71 d$ & $10.26 b c$ \\
\hline & $\mathrm{N}_{100}$ & $10.32 \mathrm{bc}$ & $10.90 b c$ & $11.70 d$ & $10.97 \mathrm{bcd}$ & $9.76 a b$ & $10.10 \mathrm{~b}$ & $11.05 \mathrm{~cd}$ & $10.30 \mathrm{bc}$ \\
\hline \multirow[t]{3}{*}{ Biochar } & $N_{0}$ & $11.82 \mathrm{ab}$ & $10.28 \mathrm{bc}$ & $14.91 b$ & $12.34 b$ & $10.45 a b$ & $10.27 b$ & $12.47 \mathrm{~b}$ & $11.06 \mathrm{~b}$ \\
\hline & $\mathrm{N}_{50}$ & $12.21 \mathrm{ab}$ & $14.04 a$ & $16.01 a$ & $14.09 a$ & $11.59 a$ & $12.66 a$ & $14.41 a$ & $12.89 a$ \\
\hline & $\mathrm{N}_{100}$ & $12.42 \mathrm{a}$ & $14.09 a$ & $16.26 a$ & $14.26 a$ & $11.04 a b$ & $13.75 a$ & $15.41 \mathrm{a}$ & $13.40 \mathrm{a}$ \\
\hline \multirow[t]{3}{*}{ Straw } & $N_{0}$ & $9.71 \mathrm{c}$ & $10.14 b c$ & $11.41 d$ & $10.42 \mathrm{~cd}$ & $9.58 a b$ & $10.12 b$ & $10.69 d$ & $10.13 b c$ \\
\hline & $\mathrm{N}_{50}$ & 10.70abc & $10.64 b c$ & $13.77 \mathrm{c}$ & $11.70 b c$ & 10.70ab & $10.41 b$ & $11.54 \mathrm{bcd}$ & $10.88 \mathrm{~b}$ \\
\hline & $\mathrm{N}_{100}$ & $11.08 \mathrm{abc}$ & $11.19 b$ & $14.19 b c$ & $12.15 b$ & 10.92ab & $10.99 b$ & $12.10 \mathrm{bc}$ & $11.34 b$ \\
\hline
\end{tabular}

3 Values with different letters within a column are significantly different at $\mathrm{p}<0.05 . n=3$.

4 
Table 6(on next page)

Cumulative $\mathrm{N}_{2} \mathrm{O}$ emissions of spring wheat as affected by carbon addition sources 
1

\begin{tabular}{llllll}
\hline \multirow{2}{*}{ C source } & Treatment & \multicolumn{5}{l}{} \\
& $\mathrm{N}$ rates & \multicolumn{2}{c}{$\mathrm{N}_{2} \mathrm{O}\left(\mathrm{kg} \mathrm{ha}^{-1}\right)$} & & \\
\cline { 3 - 6 } No carbon & & 2014 & 2015 & 2016 & Mean \\
& $\mathrm{N}_{0}$ & $3.10 \mathrm{a}$ & $2.09 \mathrm{ab}$ & $2.00 \mathrm{ab}$ & $2.40 \mathrm{ab}$ \\
& $\mathrm{N}_{50}$ & $3.17 \mathrm{a}$ & $2.00 \mathrm{ab}$ & $1.75 \mathrm{bc}$ & $2.31 \mathrm{abc}$ \\
& $\mathrm{N}_{100}$ & $3.21 \mathrm{a}$ & $2.37 \mathrm{a}$ & $2.11 \mathrm{a}$ & $2.56 \mathrm{a}$ \\
& & & & \\
Biochar & $\mathrm{N}_{0}$ & $2.37 \mathrm{~b}$ & $1.50 \mathrm{c}$ & $1.32 \mathrm{c}$ & $1.73 \mathrm{c}$ \\
& $\mathrm{N}_{50}$ & $2.47 \mathrm{~b}$ & $1.73 \mathrm{bc}$ & $1.41 \mathrm{c}$ & $1.87 \mathrm{bc}$ \\
& $\mathrm{N}_{100}$ & $2.48 \mathrm{~b}$ & $1.77 \mathrm{bc}$ & $1.42 \mathrm{bc}$ & $1.89 \mathrm{bc}$ \\
& & & & \\
Straw & $\mathrm{N}_{0}$ & $2.43 \mathrm{~b}$ & $1.87 \mathrm{bc}$ & $1.24 \mathrm{c}$ & $1.85 \mathrm{bc}$ \\
& $\mathrm{N}_{50}$ & $2.83 \mathrm{ab}$ & $1.78 \mathrm{bc}$ & $1.54 \mathrm{abc}$ & $2.05 \mathrm{abc}$ \\
& $\mathrm{N}_{100}$ & $2.99 \mathrm{a}$ & $1.98 \mathrm{ab}$ & $1.61 \mathrm{abc}$ & $2.19 \mathrm{abc}$ \\
\hline
\end{tabular}

2 Values with different letters within a column are significantly different at $\mathrm{p}<0.05$.

3

4

5

6

7

8

9

10

11

12

13

14 
Table 7 (on next page)

Cumulative $\mathrm{CH}_{4}$ emissions of spring wheat as affected by different treatment 
1

\begin{tabular}{|c|c|c|c|c|c|}
\hline \multicolumn{6}{|c|}{ Treatment } \\
\hline \multirow[t]{2}{*}{$\mathrm{C}$ source } & \multirow[t]{2}{*}{$\mathrm{N}$ rates } & \multicolumn{4}{|c|}{$\mathrm{CH}_{4}\left(\mathrm{~kg} \mathrm{ha}^{-1}\right)$} \\
\hline & & 2014 & 2015 & 2016 & Mean \\
\hline \multirow[t]{3}{*}{ No carbon } & $\mathrm{N}_{0}$ & $-1.80 \mathrm{a}$ & $-1.79 a$ & $-2.83 a$ & $-2.14 \mathrm{a}$ \\
\hline & $\mathrm{N}_{50}$ & $-1.85 \mathrm{ab}$ & $-2.07 \mathrm{a}$ & $-3.12 \mathrm{ab}$ & $-2.35 \mathrm{ab}$ \\
\hline & $\mathrm{N}_{100}$ & $-2.08 b c$ & $-2.00 \mathrm{a}$ & $-3.13 a b c$ & $-2.40 a b c$ \\
\hline \multirow[t]{3}{*}{ Biochar } & $\mathrm{N}_{0}$ & $-2.09 b c$ & $-3.14 c$ & $-3.31 \mathrm{abc}$ & $-2.85 b c$ \\
\hline & $\mathrm{N}_{50}$ & $-2.13 b c$ & $-2.23 \mathrm{ab}$ & $-3.38 \mathrm{abc}$ & $-2.58 \mathrm{abc}$ \\
\hline & $\mathrm{N}_{100}$ & $-2.19 c$ & $-3.29 c$ & $-3.70 c$ & $-3.06 c$ \\
\hline \multirow[t]{3}{*}{ Straw } & $\mathrm{N}_{0}$ & $-1.91 \mathrm{abc}$ & $-2.16 \mathrm{ab}$ & $-3.19 a b c$ & $-2.42 \mathrm{abc}$ \\
\hline & $\mathrm{N}_{50}$ & $-1.96 a b c$ & $-2.21 \mathrm{ab}$ & $-3.32 \mathrm{abc}$ & $-2.50 \mathrm{abc}$ \\
\hline & $\mathrm{N}_{100}$ & $-2.10 b c$ & $-2.54 b$ & $-3.61 b c$ & $-2.75 a b c$ \\
\hline
\end{tabular}

Values with different letters within a column are significantly different at $\mathrm{p}<0.05$.

2

3

4

5

6

7

8

9

10

11

12

13

14

15

16

17

18

19

20

21

22 
Table 8(on next page)

Biomass yield of spring wheat as affected by different treatment 
1

2

\begin{tabular}{|c|c|c|c|c|c|}
\hline \multicolumn{6}{|c|}{ Treatment } \\
\hline \multirow[t]{2}{*}{ C source } & \multirow[t]{2}{*}{$\mathrm{N}$ rates } & \multicolumn{4}{|c|}{ Biomass yield $\left(\mathrm{kg} \mathrm{ha}^{-1}\right)$} \\
\hline & & 2014 & 2015 & 2016 & Mean \\
\hline \multirow[t]{3}{*}{ No carbon } & $\mathrm{N}_{0}$ & $2776 \mathrm{~d}$ & $3030 \mathrm{~d}$ & $2455 \mathrm{~d}$ & $2754 \mathrm{c}$ \\
\hline & $\mathrm{N}_{50}$ & $3102 c$ & $3358 b c d$ & $3022 c$ & $3161 b c$ \\
\hline & $\mathrm{N}_{100}$ & $3399 b c$ & $3739 b$ & $3267 b c$ & $3468 b$ \\
\hline \multirow[t]{3}{*}{ Biochar } & $\mathrm{N}_{0}$ & $3295 b c$ & $3530 \mathrm{bc}$ & $3147 \mathrm{bc}$ & $3324 b$ \\
\hline & $\mathrm{N}_{50}$ & $3489 b$ & $3767 b$ & $3331 b c$ & $3529 b$ \\
\hline & $\mathrm{N}_{100}$ & $4291 \mathrm{a}$ & $4630 \mathrm{a}$ & $3788 \mathrm{a}$ & $4236 a$ \\
\hline \multirow[t]{3}{*}{ Straw } & $\mathrm{N}_{0}$ & $3170 \mathrm{bc}$ & $3312 \mathrm{~cd}$ & $3118 b c$ & $3200 b c$ \\
\hline & $\mathrm{N}_{50}$ & $3403 b c$ & $3765 b$ & $3365 b$ & $3511 b$ \\
\hline & $\mathrm{N}_{100}$ & $4082 \mathrm{a}$ & $4345 \mathrm{a}$ & $3633 a$ & $4020 b$ \\
\hline
\end{tabular}

3 
Table 9 (on next page)

Grain yield of spring wheat as affected by different treatments 
2

\begin{tabular}{|c|c|c|c|c|c|}
\hline \multicolumn{4}{|c|}{ Treatment } & & \\
\hline \multirow[t]{2}{*}{$\mathrm{C}$ source } & \multirow[t]{2}{*}{$\mathrm{N}$ rates } & \multicolumn{2}{|c|}{ Grain yield $\left(\mathrm{kg} \mathrm{ha}^{-1}\right)$} & \multirow[b]{2}{*}{2016} & \multirow[b]{2}{*}{ Mean } \\
\hline & & 2014 & 2015 & & \\
\hline \multirow[t]{3}{*}{ No carbon } & $\mathrm{N}_{0}$ & $1305 d$ & $1500 d$ & $1009 d$ & $1271 d$ \\
\hline & $\mathrm{N}_{50}$ & $1538 \mathrm{~cd}$ & $1896 b c$ & $1043 \mathrm{~cd}$ & $1492 \mathrm{bcd}$ \\
\hline & $\mathrm{N}_{100}$ & $1770 \mathrm{abc}$ & $1927 b c$ & $1144 \mathrm{~cd}$ & $1614 \mathrm{~cd}$ \\
\hline \multirow[t]{3}{*}{ Biochar } & $\mathrm{N}_{0}$ & $1603 \mathrm{bcd}$ & $1789 \mathrm{~cd}$ & $1124 \mathrm{~cd}$ & $1505 \mathrm{bcd}$ \\
\hline & $\mathrm{N}_{50}$ & $1905 \mathrm{abc}$ & $2133 b$ & $1233 b c$ & $1757 \mathrm{abc}$ \\
\hline & $\mathrm{N}_{100}$ & $2139 a$ & $2456 a$ & $1567 \mathrm{a}$ & $2054 \mathrm{a}$ \\
\hline \multirow[t]{3}{*}{ Straw } & $\mathrm{N}_{0}$ & $1502 \mathrm{~cd}$ & $1658 \mathrm{~cd}$ & $1111 \mathrm{~cd}$ & $1424 \mathrm{~cd}$ \\
\hline & $\mathrm{N}_{50}$ & $1852 \mathrm{abc}$ & $1944 b c$ & $1182 \mathrm{~cd}$ & $1659 \mathrm{bc}$ \\
\hline & $\mathrm{N}_{100}$ & $1975 \mathrm{ab}$ & $2180 \mathrm{ab}$ & $1380 \mathrm{ab}$ & $1845 \mathrm{ab}$ \\
\hline
\end{tabular}

3 
Figure 1

Precipitation (mm) in 2014, 2015 and 2016 cropping season at the experimental site 

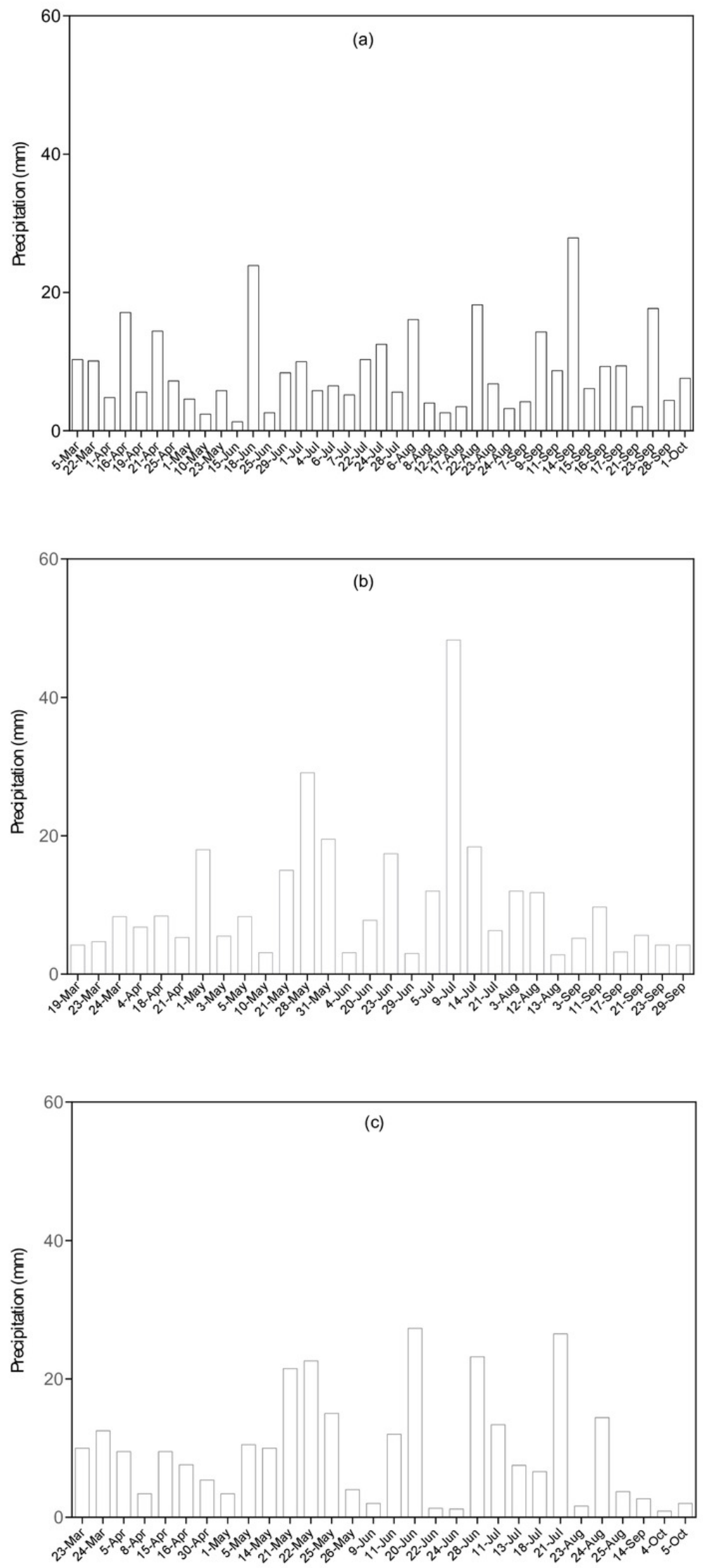

PeerJ reviewing PDF | (2021:01:57597:2:0:NEW 3 Jul 2021) 
Figure 2

Seasonal $\mathrm{N}_{2} \mathrm{O}$ fluxes for spring wheat in 2014 (a), 2015 (b) and 2016 (c) as affected by carbon addition sources.

The vertical bars represent the least significant difference (LSD) at ${ }_{p}<0.05$ among treatments within a measurement date

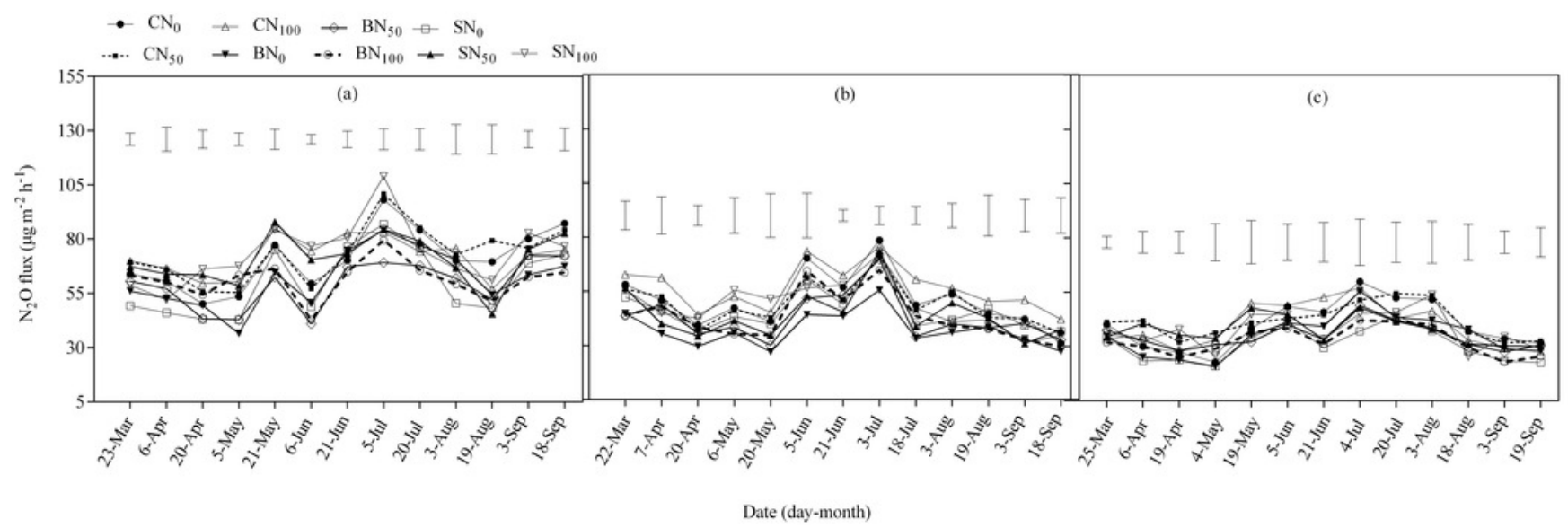


Figure 3

Seasonal $\mathrm{CH}_{4}$ fluxes for spring wheat in 2014 (a), 2015 (b) and 2016 (c) as affected by carbon addition sources.

The vertical bars represent the least significant difference (LSD) at ${ }_{p}<0.05$ among treatments within a measurement date

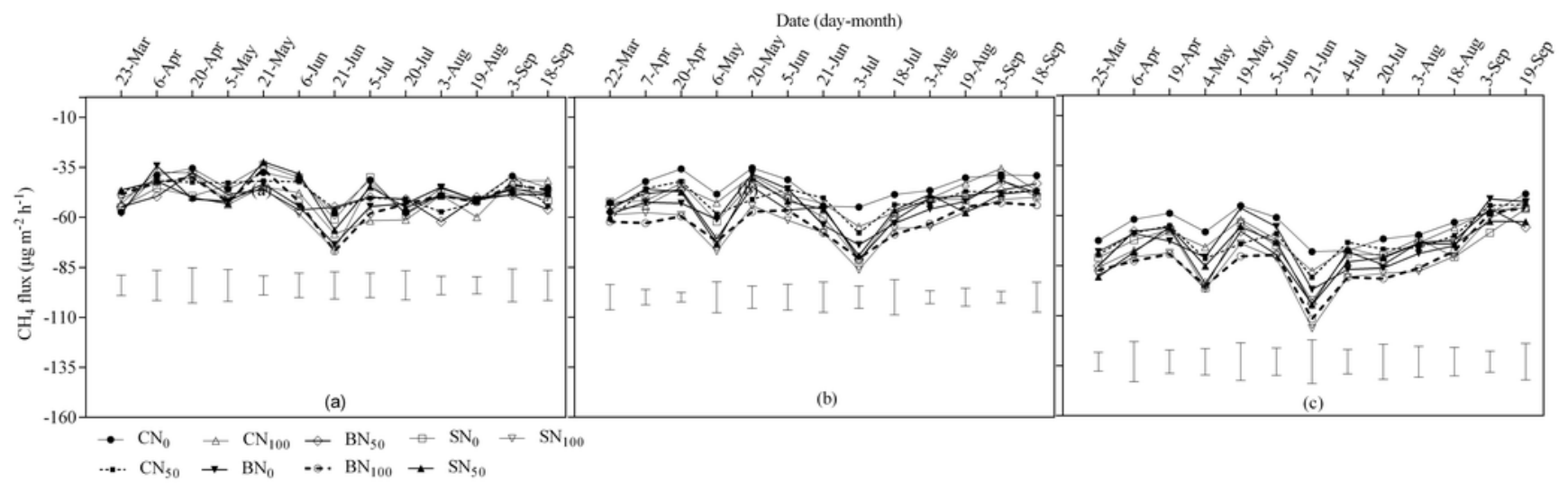

